\title{
Determinants of Environmental Product Innovation in the Detergent and Maintenance Sector: Application for the European Ecolabel Certification
}

\author{
Amara Mehamli \\ Correspondence: Amara Mehamli, CERGAM, Faculty of Economics and Management (FEG), University of \\ Aix-Marseille, France. E-mail: amara.mehamli@hotmail.fr \\ Received: May 25, 2012 \\ Accepted: June 7, 2012 \\ Online Published: December 31, 2012 \\ doi:10.5539/ibr.v6n2p51 \\ URL: http://dx.doi.org/10.5539/ibr.v6n2p51
}

\begin{abstract}
The aim of this article is to determine the relevant factors of environmental product innovation. In the sector of detergent and maintenance products the European Ecolabel certification, as an environmental voluntary policy, is considered one of multiple kinds of environmental innovation. According to the empirical analysis (a survey was conducted in the French market) we find that the strategy of the biotechnological firm, the market demand, the certification benefits (brand image) and policy regulation (REACH directive...) seem to be important factors in the European Ecolabel certification. Although, this voluntary policy drives some firms to innovation, the environmental performance and accession of the most firms in this sector are still a challenge. Firms which have used biomolecular substances, under suppliers' incentives effect, have not systematically developed European Ecolabel certified products.
\end{abstract}

Keywords: environmental product innovation, green product, environmental policies, technical change, European Ecolabel certification

\section{Introduction}

The development of concentrated products, the use of a new natural and renewable biomolecular substances (Note 1), reduction of waste (use of more compact, recyclable, biodegradable packaging, etc.) and water consumption, the implementation of environmental certifications, the code of good environmental practice and Charter fort Sustainable Cleaning, etc., are key initiatives in the sector of detergents and maintenance products to reduce pollution, consumption of resources and impact on community/users health. This new industry (biotechnology and green chemistry) focuses on the natural properties of plants and/or microorganisms to develop (with new molecules) more safe and environmentally friendly detergents, maintenance products and packaging.

Nevertheless, despite the impressive progress in this sector (more than $18 \%$ production growth) between the two periods 2009 and 2010, environmentally friendly detergents and maintenance products (so-called "green products") represented only 3\% of the market, in 2008 (Note 2). In France, in 2009, 97\% of the manufactured products were from petrochemical origin, according to the Chemical Union Industries (CUI) (Note 3). These results show the effort still needed by the major players in this industry to make this activity less polluting and less dangerous to the health of users.

The response of firms to this negative externality, generated by these kinds of products in their process of production and consumption, and the need to clean, degrease, disinfect, etc, various public, private and industrial sites, is not limited by the development of green chemistry products. Other solutions are proposed at the same time by other actors (development of the steam bio-cleaning, cleaning machines that do not rely upon chemical products, etc.). However, the solutions presented in the sectors of green chemistry and environmental biotechnology still dominate the industry. In the registry, an incentive for firms to accelerate their ecological transformation, the European policy within this sector has introduced, since 1992, a new environmental voluntary program (European Ecolabel product certification) and, from 2007, a new regulation kowns as the REACH directive. 

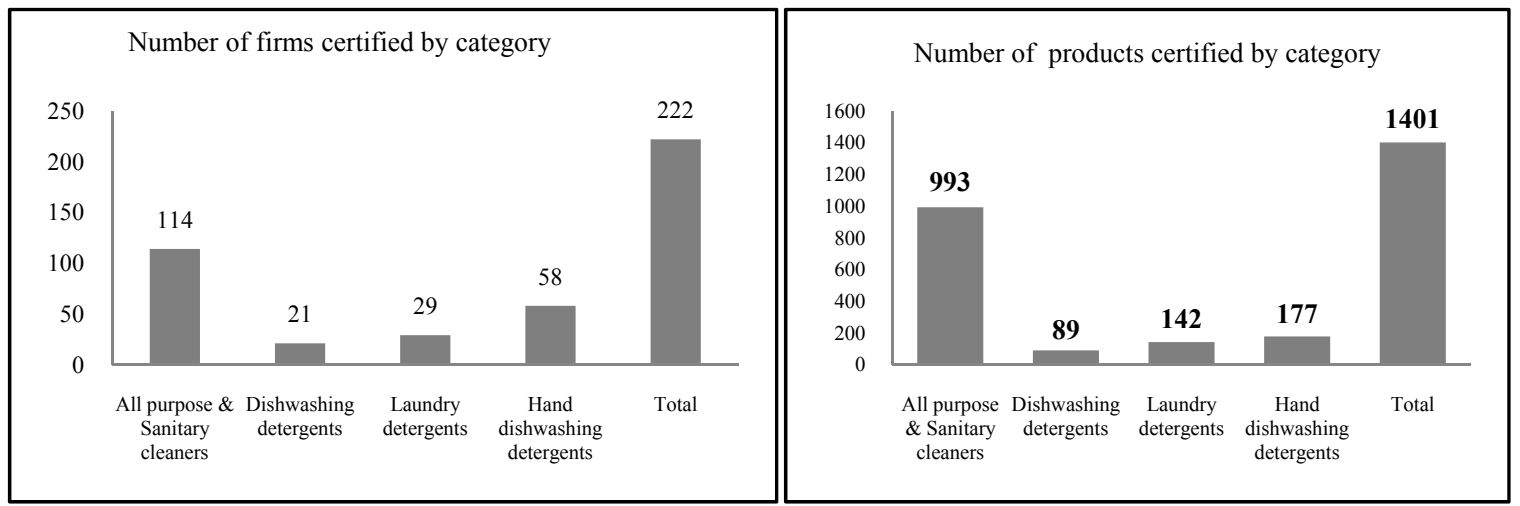

Figure 1. Number of firms and products certified (2009)

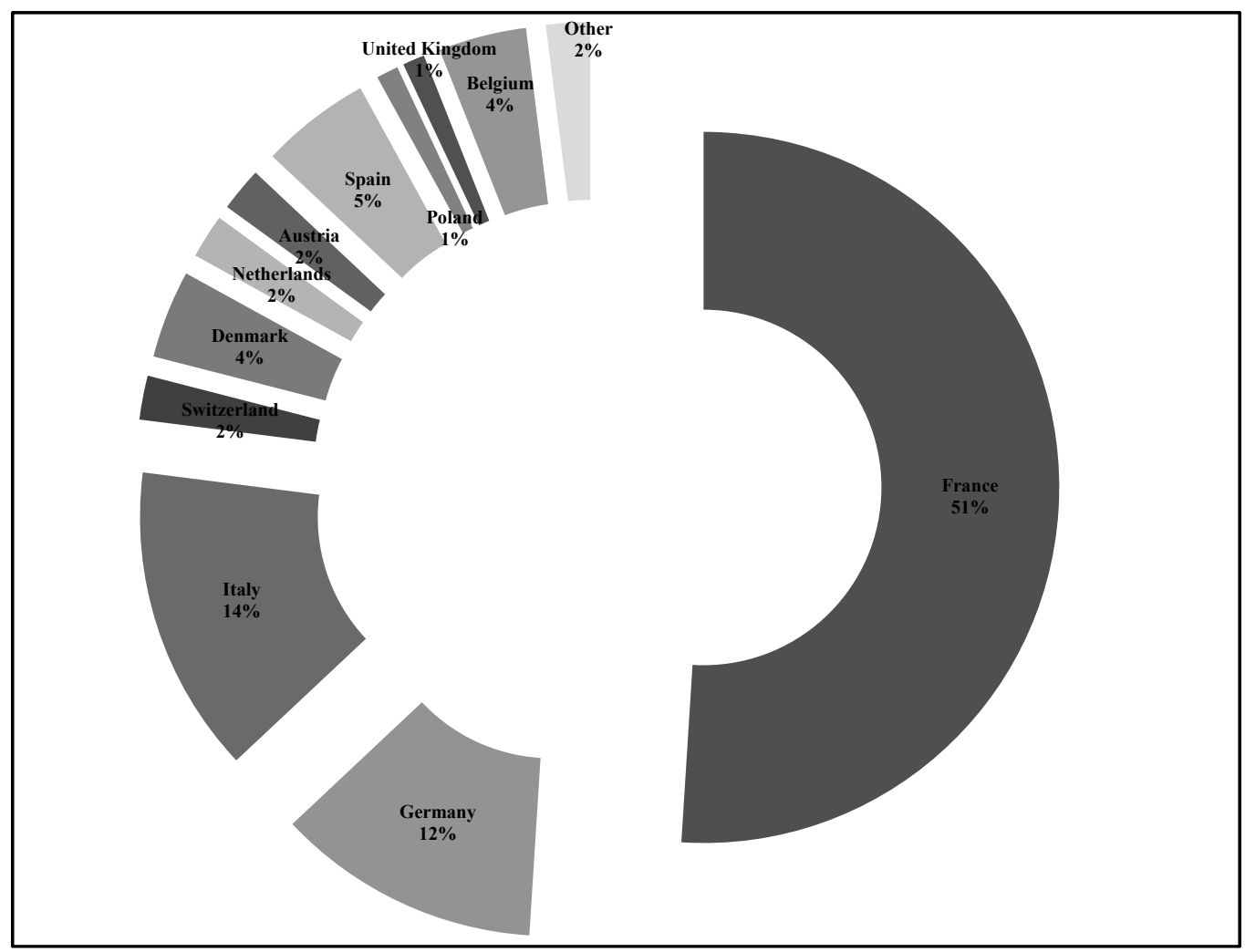

Figure 2. Percentage of reference by country (2009)

Source: European Commission Environment.

The European Ecolabel certification allowed the development of new environmental innovations, essentially environmentally friendly products. Indeed, we have registered, in France, an increase in the number of companies that have adopted this new environmental certification (See figures 1 and 2). However, its market share is still low and addressed mainly to green consumer (Rex and Baumann, 2007) (Note 4). The European Ecolabel is in part a response of firms to positive and negative externalities problems (since it also partly delayed the transfer of knowledge). First, it represents the effort of the firm in terms of R\&D (step 1) and then the certification process (step 2).The culmination of this decision to innovate is not guaranteed and several factors can guide its direction and influence its place.

We examine in this work relevant determinants of European Ecolabel product certification. After a review of literature on determinants of environmental innovation products and chemical sector studies, we will analyze the results of the survey implemented in French market, between 2009 and 2010. Our analysis is based on a logistic regression model to highlight the key determinants of this category of products. Given the number of factors which 
may influence the decision to adopt (in sense of R\&D programs and certification processes) European Ecolabel certification, we will focus our analysis in this model on the role of firm strategies (the biotech companies that provide biomoleculars), R\&D, ISO 9001 certification, environmental demand and Regulation (REACH directive, etc.). Indeed, as this certification does not require the use of biomolecular substances, biotechnologies firms can influence the rate and direction of innovation in the sector, through their business and marketing strategies.

\section{Review of the Literature}

The economic literature makes different assumptions about the determinants of environmental innovation products (green products). The evolutionary economic approach is interested in the role and the real impact of environmental policies on innovation and diffusion. Without failing to integrate different internal and external factors into the firm, it finds that these policies have a mixed role. Environmental innovation, depending on the context, is mainly driven by various factors that influence not only the rate and the direction of technical change but also the nature of innovation (Del Río, 2009). Among the main determinants, that are often integrated in the analytical and empirical literature are the following: the market, technological opportunities, environmental policy, environmental strategy and organizational and technological absorption capacity (Note 5). The works within management science's "firm strategy" and economic theory's "environmental economics" focus on the possible link between environmental policy and environmental innovation. The Porter and Van Der Linde (1995) hypothesis is, indeed, at the centre of these studies. Several empirical studies have also attempted to confirm this relationship. Current studies still show mixed results primarily because of the methodological difference, the complexity of the process, the role of other factors, the problem of data and, finally, the characteristics of environmental policy - context, type of instruments, form and timing, etc. (Kemp \& Pontoglio, 2008). Thus, some analyses focus primarily on the role of environmental policies (Note 6).

In the lineage of the industrial and innovation economy, the current literature also stresses the importance of technological factors (technology push) and market demand (market pull) (Turpitz, 2004). It recognizes the weight of the market (Schmookler, 1966) and technological (Mowery \& Rosenberg, 1979) opportunities in the innovation process. It is accepted that there is a certain primacy of technological progress in the initial phase of innovation and a primacy of market in the diffusion phase (Pavitt 1984). Cleff and Rennings (1999) have combined these three main factors (supply, demand and regulation factors) attempting to identify the key determinants of environmental innovation. Within this literature, attention has also been paid to other internal and external factors some of which are usually reserved for management sciences (from the literature on the firm environmental strategy, to the theory of organizations and eco-marketing) (Note 7). Thus, current studies incorporate other factors and also make a distinction between product and process innovation.

The Turpitz (2004) case analysis suggests that environmentally innovative product is primarily driven by four important factors: technology, market, environmental policies and factors internal to the firm. Cleff and Rennings (1999) report the influence of the market and the role of voluntary instruments (ISO 14001, certification ecolabel, eco-audit...). The ecolabel certification in Germany (Blue Angel) strongly stimulates product innovation. The work of Ziegler (2005) demonstrates these results. Environmental innovation products and processes are effectively linked to technological opportunity, the incentive of the market (market pull) and the implementation at the organizational level of environmentally specific measures (primarily the ISO 14001). Rehfeld et al. (2007) found significant results regarding the implementation of environmental management systems and environmental innovation products. The role of other factors, such as regulation, market, technology and the specificities of the firm is also demonstrated in this empirical study. The results of the logistic regression of Kammerer (2009) show the role played by the regulation and the consumer benefit (due to the benefits and the quality of the product). They encourage not only the development of new innovations, but also the scope of their application and the degree of novelty. The empirical results of the study presented by Horbach (2008) show the importance of technological capacity (capital Knowledge), enhanced by the R\&D, in the process of environmental innovation. The hypothesis that innovation promotes the emergence and the development of other innovations was confirmed in this case. In addition, Porter's hypothesis is confirmed in this study. Finally, regulation, environmental management tools, and organizational change also stimulate environmental innovation.

Kivimaa (2007) examines how environmental policies, market factors and technological opportunities (technology push) affect the innovation products and processes in areas of pulp, paper and packaging in the Nordic countries. The results show that the three factors are positively significant. Environmental innovation is often developed to anticipate or to comply with the regulation. It (regulation) seems to have a direct effect on innovation processes, which is not confirmed in the case of innovation product. The work of Triebswetter and Wackerbauer (2008) confirm the positive impact of these three factors. Not only regulatory pressure, but also the pressure of costs, the competitive advantage, the effect of the technological opportunities and consumer pressure are important to 
transcend the inertia within the firm and develop innovation. Incentives through market (Germany, 1999-2006) and finance law (France, 2005-2009) have indeed had positive results, according to the comparative study of the quality labels and existing standards, related to Small Scale Biomass Heating Systems (BHS) (Verma et al., 2009). $76.8 \%$ of environmental innovation is "product innovation", according to the study by Frondel et al. (2007). The multinomial logistic model estimated on this study indicates that the strengthening of environmental policies and regulatory measures are positively correlated with "end-of-pipe" innovation, while the reduction of costs, the managerial system and some environmental management tools tend to foster innovative products. Indeed, the ISO 14001 certification is particularly effective for the creation of the best conditions for technological change, within the companies who are invested in the IPPC (Note 8) directive (Radonji \& Petra, 2007).

The results of Becker and Englmann (2005) corroborate that environmental regulation is, by far, the main incentive in the chemical industry for "end-of-pipe" innovation and "production-integrated innovation". Berkhout et al. (2003) examined the potential impact of the new chemicals legislation (REACH) on innovation, competitiveness and employment in the EU. They conclude that many of these provisions tend to foster innovation, even beyond this sector. They add that the positive impacts on industrial innovation can take some time. Nordbek and Faust (2003) also discuss this European policy. They reject the hypothesis that the regulation limits innovation because of the arguments weakness and the lack of evidence. Instead, they advocate the development of other tools and support for these measures. Others authors have also brought to light additional evidence about the Porter hypothesis and the role of environmental policies in the chemical industry. Oosterhuis (2006) shows clearly that there is no conflict between innovation and environmental policy. There are many indications that innovation is more important in countries where more active substitution policy in chemical industry is pursued (e.g. Sweden and Denmark). Nameroff et al. (2004) explain that the growth of the environmental patent in the chemical industry in the USA coincides with the revision of the environmental laws in the 1980s and 1990s. However, the low rate of relationship between these innovations and non-environmental innovation, suggests that these industries have not necessarily embraced green chemistry as a means to reduce regulatory pressure. Seija Nogareda (2007) study in the sector of chemistry and pharmacy has shown that demand, the regulatory stringency and a greater distance from the end consumer in the supply chain influenced positively the amount of product innovations. In the case of the innovation of processes, regulatory stringency and quantity also had a positive impact, as well as firm size and corporate environmentalism. Finally, regulation, as a signal of market change and the need to anticipate it, in addition to the commercial and technological aspects, are the main factors that have influenced the development of more environmentally friendly products in the chemical sector, according to the Visser et al. (2008) study. The role of commercial staff, R\&D managers and CEOs is vital in this process. This study also highlights the minor role of EHS managers.

\section{The Model Specification and Data}

\subsection{Assumptions and Theoretical Model}

We can distinguish three external factors which work to stimulate the firm in the sector of detergents and maintenance products. The first factor which promotes innovation is the importance of environmental criteria in the firm choice (Horbach, 2008; Reheld et al., 2007). In order to meet environmentally friendly products demand the firm can anticipate regulatory measures and product innovation to have a competitive advantage. H1: the more important environmental criteria are considered, the more companies will tend to innovate European Ecolabel certified products. The second stimulating factor concerns the suppliers. They play a significant role to promote firm innovation (Arundel \& Rose, 1999; Montalvo, 2008; Visser et al., 2008). The provider of biomoleculars develops a strategic plan to promote innovation and encourage the adoption of the product by new users. Entrepreneurship plays a significant role in the implementation of this strategy. Incentives through business and marketing strategy are the best way for this task (Rogers, 1995; Anderson \& Gatignon, 2003). H2: suppliers introduce business and marketing incentives which accentuate the likelihood of adoption of biomoleculars and thus the European Ecolabel certified product.

The push/pull regulation approach (Cleff \& Rennings, 1999; Rennings, 2000) incorporates the impact of environmental policies on innovation, which represents a relatively important factor (Porter \& Vand Der Linde, 1995, Green et al., 1994; Seija Nogareda, 2007; Nameroff et al., 2004). H3: regulation would encourage company's environmental product innovation and adoption of the European Ecolabel certification (Note 9).

Barriers and performances (benefits) of the European Ecolabel certification should also enable (or discourage) innovation within the firm. H4: the presence of strong benefits to certification would encourage company adoption; H5: the presence of strong barriers to certification would discourage company adoption. 


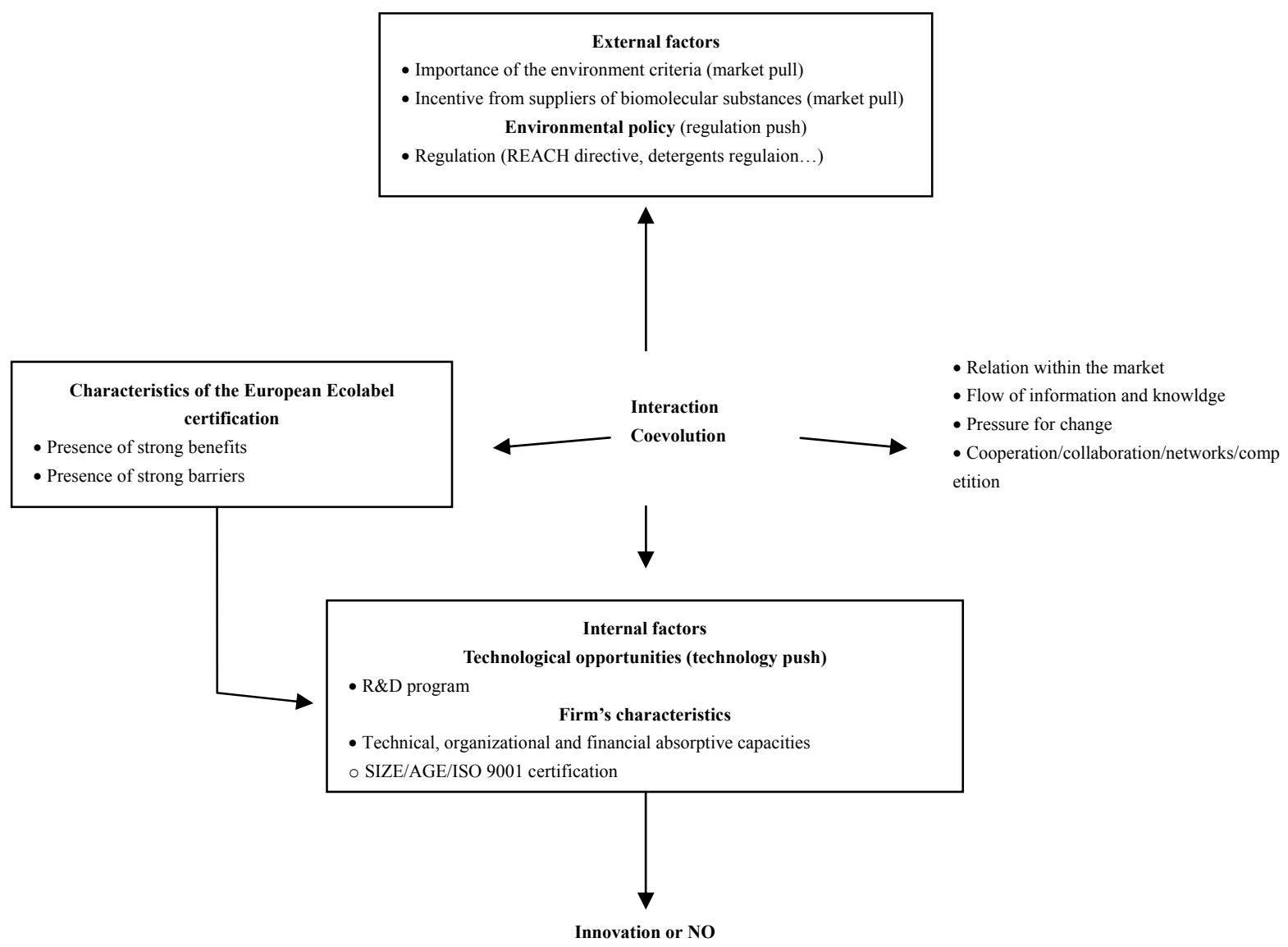

Source: adapted from Del Río (2005) (Note 10).

Figure 3. Theoretical model

Finally, there is interest in this analysis, to internal factors at the firm which can impede or accelerate environmental innovation. The technological, organizational and financial absorption capacity differs from one firm to another and from one sector to the other. Internally, the firm with a better absorptive capacity facilitates and promotes innovation. This ability was analyzed in the literature addressing various factors.

The technological capability of the firm to innovate is relative to its ability to implement a program of research and development with the goal of developing green products (Horbach, 2008; Rehfeld et al., 2007). H6: the establishment of $R \& D$ programs should spur innovation and the European Ecolabel certification adoption.

Companies with a larger workforce, more experience and which use high quality production process according to the ISO 9001 standards should have a greater capacity to innovate (Horbach, 2008; Montalvo, 2008; Del Río, 2005; Traore \& Rose, 2003; Rehfeld et al., 2007). H7: the greater number of employees a company has, the greater innovative capacity it will have; H8: companies with greater experience (in their workforce), will have greater innovative capacity; H9: firms with ISO 9001 certification have better routines and process of innovation and European Ecolabel certification. The figure 3 summaries all this hypothesis.

\subsection{Variables}

The table 1 gives a list of explanatory variables. The dependant variable is represented by "EUPECOL". With a logistic regression analysis our model assumes the presence (or not) of a competitive environment, in which the probability of adoption of European Ecolabel certification is (or is not) in competition with the likelihood to adopt other certifications. The firm, in a complex environment, with a several incentives (incentives from the market, the regulation, suppliers, etc.) and its own R\&D program and/or quality process (ISO 9001 or not), can choose to adopt (or not) European Ecolabel certification instead of other types of certifications of products or processes (Ecocert, ISO 14001/EMAS and LCA) (Note 11) or to not adopt any of these forms of certification. In addition, there is (or not), in same time, a competition between a biomolecular substances and other substances (e.g. petrochemical). Thus, a business and marketing strategy from suppliers of biomolecular substances can also (but will not 
necessarily) affect this certification decision. Finally, the firm can also focus on purely strategic considerations (e.g. the search for an environmental image), which can be a vital point in the final decision of the firm.

Table 1. Explanatory variables

\begin{tabular}{lllc}
\hline Variable & Definition & Coding & Hypothesis \\
\hline SIZE & Number of employees & 1 if the firm is big, 2 medium and 3 small (Note 12) & H7 \\
AGE & Years of set up & 1 if the firm is old, 2 medium and 3 young (Note 13) & H8 \\
ISO & ISO 9001 certification & 1 if yes, 0 otherwise & H9 \\
ENVCRI & Environmental criteria importance & 1 if yes, 0 otherwise & H1 \\
SUPINC & Incentives from suppliers of biomolecular substances & 1 if yes, 0 otherwise & H2 \\
R\&D & R\&D program & 1 if yes, 0 otherwise & H6 \\
ENREGL & Environmental regulation & 1 if yes, 0 otherwise & H3 \\
ECOLBE & Presence of strong benefits & 1 if yes, 0 otherwise & H4 \\
ECOLBA & Presence of strong impediments or barierres & 1 if yes, 0 otherwise & H5 \\
\hline
\end{tabular}

\subsection{The Sample and the Data}

A questionnaire was mailed to 336 firms engaged in the professional French market in the area of detergents and maintenance products (formulators, manufacturers and distributors under (2041Z) INSEE (Note 14) national classification). A crossing data was made between internet firm data bases too. The questionnaire was mailed mainly to the CEO's, general manager or the R\&D, laboratory and/or purchasing manager. We had 44 responses from this population. Although it is difficult for us to have the market share of this respondent population, these companies however are the most important players on the market (they represent at least $30 \%$ of market share). SPSS logistic regression analysis, as we will see, saves only 30 firms on the sample, because of missing values.

\section{The Empirical Results and Discussion}

\subsection{Descriptive Analysis}

The descriptive analysis allowed us to obtain valuable information about the characteristics of the sample:

- More than $65 \%$ of firms are set up for more than 20 years;

- Only 36\% are group subsidiary;

- More than 52\% of companies have equal to or more than 50 employees, $47 \%$ between 51 and 500 employees;

- $59 \%$ of firms interviewed carryout formulation, manufacture and distribution activity;

- $88 \%$ of them have developed at least one environmental innovation product, $40 \%$ a Ecocert certified products and $47 \%$ a European Ecolabel certified products;

- ISO 9001 certification represents $64 \%$ in the sample. Only $34 \%$ and $23 \%$ of companies surveyed have adopted an EMAS/ISO 14001 certification and/ or LCA respectively;

- $80 \%$ of firms say that there are barriers to the use of biomolecular substances;

- $70 \%$ agree that there are strong benefits to the European Ecolabel certification. However, $84 \%$ also recognize the presence of strong barriers to the European Ecolabel certification.

In addition, this study offers the possibility to identify the main impediment to use or adoption of biomolecular substances.

In figure 4 we can see enzymatic natural products are mainly constrained by the cost price, the major impediment (with 21 "YES" answers). Four barriers are identified in the case of natural plant products. The cost (with 33 "YES" answers), competitiveness (with 29 "YES" answers), Unknown (with 26 "YES" answers) and technical performance (with 21 "YES" answers). Four barriers are also identified in the case of biosurfactants. The cost (with 21 "YES" answers), competitiveness (with 24 "YES" answers), unknown (with 20 "YES" answers) and availability (with 20 "YES" answers).

The European Ecolabel is a very effective way to improve brand image (Figure 5). Indeed, it combines an acceptable performance (regarding safety, technology and environment) and, at the same time, provides a good image of the company and its products. Despite its advantages, the development of European Ecolabel certified products is limited primarily by the competitiveness of traditional products, the cost of certification, the price of the final product and non valuation of natural products (biomolecular substances). 

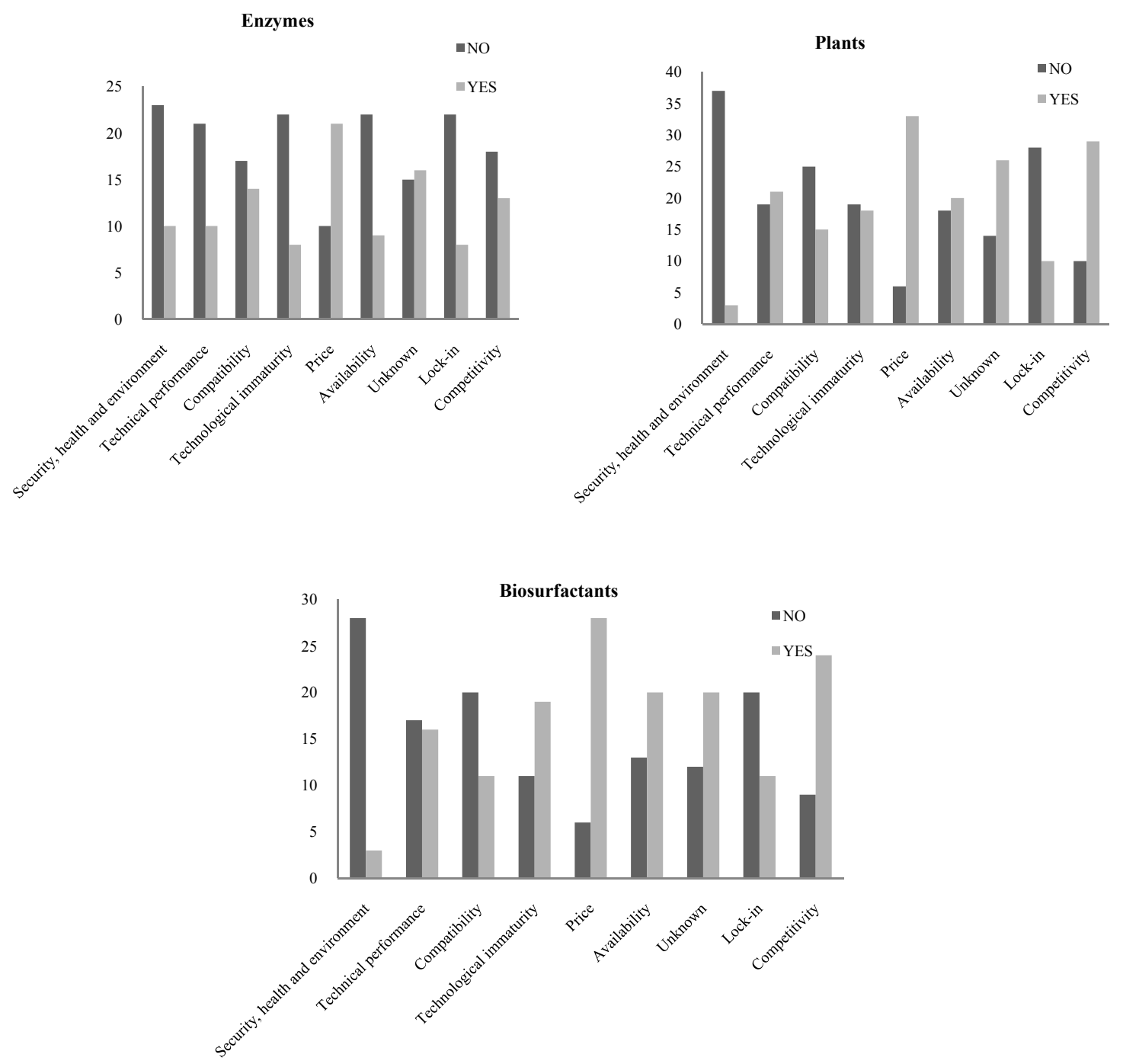

Figure 4. The nature of barriers in the adoption of biomolecular substances

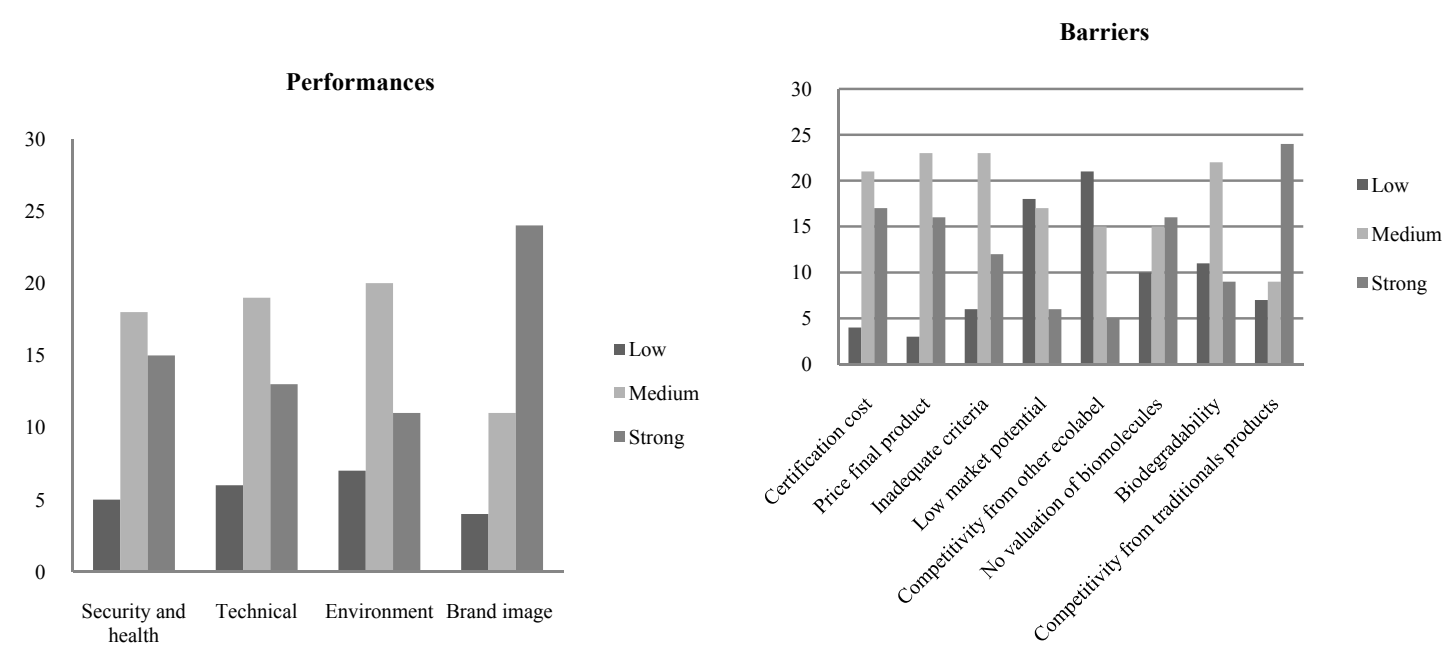

Figure 5. Performances and barriers of the European Ecolabel certification 


\subsection{Logistic Regression Results}

The correlation matrix (Table 2) shows the absence of a strong and direct relationship between the independent variables, which demonstrates the quality of the model.

Table 2. Correlation

\begin{tabular}{lllllllllll}
\hline & & SIZE & AGE & ENVCRI & SUPIN & R\&D & ENREGL & ISO & ECOLBE & ECOLBA \\
\hline SIZE & C Pearson & 1 & .214 & .176 & .015 & .167 & .089 & $.325^{*}$ & .220 & .155 \\
AGE & C Pearson & .214 & 1 & -.014 & .112 & -.002 & -.134 & .054 & -.149 & -.033 \\
ENVCRI & C Pearson & .176 & -.014 & 1 & .206 & $.431^{* *}$ & .176 & -.129 & -.059 & $.374^{*}$ \\
SUPINC & C Pearson & .015 & .112 & .206 & 1 & -.182 & $.495^{* *}$ & -.126 & -.057 & -.073 \\
R\&D & C Pearson & .167 & -.002 & $.431^{* *}$ & -.182 & 1 & -.082 & .206 & .145 & .273 \\
ENREGL & C Pearson & .089 & -.134 & .176 & $.495^{* *}$ & -.082 & 1 & -.163 & .020 & .052 \\
ISO & C Pearson & $.325^{*}$ & .054 & -.129 & -.126 & .206 & -.163 & 1 & $.316^{*}$ & .082 \\
ECOLBE & C Pearson & .220 & -.149 & -.059 & -.057 & .145 & .020 & $.316^{*}$ & 1 & .100 \\
ECOLBA & C Pearson & .155 & -.033 & $.374^{*}$ & -.073 & .273 & .052 & .082 & .100 & 1 \\
\hline
\end{tabular}

Note: *. The correlation is significance at level of 0.05 (bilateral); ${ }^{* *}$. The correlation is significance at level of 0.01 (bilateral).

The model (Table 3) saves a chi-squared at 17.958 with a rate of significance of 0.036 .

Table 3. Model specification Tests

\begin{tabular}{lllll}
\hline & & Khi-Chi-deux & ddl & Sig. \\
\hline Step 1 & Step & 17.958 & 9 & .036 \\
& Bloc & 17.958 & 9 & .036 \\
& Model & 17.958 & 9 & .036 \\
\hline
\end{tabular}

The Hosmer-lemeshow statistic (Table 4) indicates that the model adequately fits the data $(0.362>0.05)$.

Table 4. Hosmer-Lemeshow test

\begin{tabular}{llll}
\hline & Khi-Chi-deux & ddl & Sig. \\
\hline Step 1 & 8.776 & 8 & .362 \\
\hline
\end{tabular}

Table 5 presents a satisfactory model, explaining $60 \%$ the dependent variable "EURECOL".

Table 5. Summary of the model

\begin{tabular}{llll}
\hline Step & $-2 \log$-vraisemblance & R-deux de Cox \& Snell & R-deux de Nagelkerke \\
\hline 1 & $22.422^{\mathrm{a}}$ & .450 & .609 \\
\hline
\end{tabular}

Note: a. Estimate iteration number 6 was interrupted because the parameter estimates have changed less .001 .

Table 6 presents a very satisfactory reclassification rate, exceeding $76 \%$.

Table 6. Classification table (1)(a)

\begin{tabular}{llllll}
\hline \multirow{2}{*}{ Observations } & & \multicolumn{2}{l}{ Prévisions } & \\
\cline { 3 - 4 } & & & \multicolumn{2}{l}{ EURECOL } & \\
\cline { 3 - 4 } & & & NO & YES & Correct percent \\
\hline Step 1 & EURECOL & NO & 8 & 4 & 66.7 \\
& & YES & 3 & 15 & 83.3 \\
& Global percent & & & & 76.7 \\
\hline
\end{tabular}

Note: a. The value of hyphenation is. 500 .

The results of logistic regression (Table 7) with SPSS analysis show that our model retains four explanatory variables, three which are significant at $5 \%$ level and one variable is at $10 \%$ level. The four variables are the importance of environmental criteria in the market, the benefits of the European Ecolabel, the incentive from biomolecular suppliers, and finally, regulation. These variables have significant results: The "ENVCRI" variable 
with a rate of significance of $(\mathrm{P}=0,026$ and a Wald $>4)$; the "ECOLBE" variable with a rate of significance of ( $\mathrm{P}$ $=0.032$ and a Wald $>4)$; the incentive for suppliers "SUPINC" with a rate of significance of $(P=0,048$, and one almost equal to 4 Wald). And finally, "ENVREGL" with a rate of significance of ( $(\mathrm{P}=0,075$ and a Wald $>3)$. "SUPINC", "ECOLBA" and "R\&D" factors affect negatively the likelihood of Europen Ecolabel certification. They reduce the likelihood of innovation as they pass from a lower level to a higher level.

Table 7. Variables in the equation

\begin{tabular}{llllllll}
\hline & A & E.S. & Wald & ddl & Sig. & Exp(B) \\
\hline${\text { Step } 1^{\mathrm{a}}}$ & SIZE & 1.037 & 1.340 & .598 & 1 & .439 & 2.820 \\
& AGE & 1.756 & 1.235 & 2.022 & 1 & .155 & 5.788 \\
ENVCRI & 4.803 & 2.157 & $\mathbf{4 . 9 5 8}$ & 1 & $\mathbf{. 0 2 6}$ & 121.907 \\
SUPINC & -6.620 & 3.345 & $\mathbf{3 . 9 1 8}$ & 1 & $\mathbf{. 0 4 8}$ & .001 \\
R\&D & -.626 & 1.806 & .120 & 1 & .729 & .535 \\
ENREGL & 4.906 & 2.752 & $\mathbf{3 . 1 7 9}$ & 1 & $\mathbf{. 0 7 5}$ & 135.110 \\
& ISO & 1.840 & 1.412 & 1.699 & 1 & .192 & 6.298 \\
ECOLBE & 3.522 & 1.647 & $\mathbf{4 . 5 7 2}$ & 1 & $\mathbf{. 0 3 2}$ & 33.861 \\
& ECOLBA & -1.321 & 1.391 & .902 & 1 & .342 & .267 \\
& Constante & $-9,095$ & 4,677 & 3,782 & 1 &, 052 &, 000 \\
\hline
\end{tabular}

Note: a. Variable(s) entered in step 1: SIZE, AGE, ENVCRI, SUPINC, R\&D, ENVREGL, ISO, ECOLBE, and ECOLBA.

European Ecolabel certified product is influenced mainly by the importance of environmental (demand) market criteria and the presence of strong benefits from its adoption. Indeed, consumers, users and different institutional organizations exercise more pressure on the sector. The presence of ecological criteria in the specifications of some procurement and some consumer demand may also explain the importance of environmental criteria. In some markets, we require even that products are certified with the European label. The importance of performance (benefits) is explained by firm strategy in looking for an environmental brand image.

The opposite relationship between the incentive from suppliers of biomolecular substances and European Ecolabel certification may be explained by its specification. In fact, one does not need to use a biomolecular raw material to develop environmental products with this certification. Thus, the more these business incentives (from suppliers) are considered important, the lower the expectation that firms will adopt the European Ecolabel certification. Firms that are stimulated by suppliers of biomolecular substances are likely to develop green product, but not systematically European Ecolabel products. Firms in this case, move towards other certifications (e.g. Ecocert) or claim simply the superiority of their own new green products (types II and III), compared with the European Ecolabel certified products (Note 15).

We can also make the same remark concerning the establishment of R\&D programs, although this last factor was not significant in our model. The companies that set up R\&D programs will likely develop products beyond the requirements of the European Ecolabel specification. They are in fact less interested in adopting it. Regulation is also an important factor. The implementation of REACH directive and the strengthening of existing regulation in this sector encourage the development of this category of products. ENVCRI, ECOLBE, SUPINC and ENVREGL are the greatest determinants that stimulate the firm's decision in this study.

\section{Conclusion}

While the effect of environmental innovation in firm performance, under environmental policies (or in their absence), is confirmed more and more within the literature (Lanoie et al., 2007), the present work shows how these policies (in particular voluntary approaches) drive production of environmentally innovative products. The results are consistent with most of studies and analyses applied in the chemical sector (Berkhout et al., 2003; Nordbek \& Faust, 2003; Oosterhuis, 2006; Seija-Nogareda, 2007; Visser et al., 2008) (Note 16). However, as it is currently designed, the European Ecolabel specification does not guarantee accession by all actors nor the optimization of environmental performance. Accessibility and acceptability of this kind of innovation, compared to others types of innovation (with or without Ecolabel certification) can explain firm adoption. Strong benefits (enhancement of brand image) from this certification can confirm this hypothesis. It can be also a consensus aimed to minimize the costs of environmental innovation, competition between strategic groups and objections to the implementation of this ecolabel (Nadai, 1998).

A mixed environmental policy (regulation and voluntary approaches) has a positive effect on green product development. This also occurs in the presence of incentives from the market, seeking more specific products. The 
supplier's business and marketing strategy drives the rate and direction of technical change, as well as competition. These findings confirm Visser et al.'s (2008) results. Thus, this technological diversity applied in actual specification, under strategies and competition effects of actors, appears to undermine the adoption of the European Ecolabel certification.

At the same time, one can note the strategic use of Ecolabel certification by firms. Some firms adopt other certifications to respond to all forms of market demand. $30 \%$ of firms reported having adopted, at the same time, Ecocert and Ecolabel European certifications, and 15\% adopted Ecolabel European certification and, at least, ISO14001/EMAS and/or LCA. These firms go beyond the regulation, they seek through this voluntary approach, on the one hand, to benefit from a brand image and, on the other hand, to generate profits by increasing market share with adapted responses to consumer needs, a win-win strategy of Porter and Van Der Linde (1995).

\section{Acknowledgements}

I want to thank my Professor Mr. Anthoine Gentier for its valuable advice. I thank also all those near or far that helped me to carry out this work.

\section{References}

Actu-Environnement. (2011). Impact environnemental des produits d'entretien et des équipements de nettoyage. Retrieved from $04 / 04 / 2011$. http://www.actu-environnement.com/ae/dossiers/hpe/verdissement-produit-nettoyage.php4.

ADEME. (2007). Des bioressources à l'industrie. Rapport d'activité. AGRICE II. Retrieved from http://www2.ademe.fr/servlet/getDoc?cid=96\&m=3\&id=40051\&p1=00\&p2=08\&ref=17597.

AFNOR. (2012). Tout savoir sur les écolabels. http://www.ecolabels.fr/fr/.

Ambec, S., \& Lanoie, P. (2008). L'innovation au service de l'environnement et de la performance économique. INRA. $\mathrm{N}^{\circ} 6 / 07$ - Février.

Anderson, E., \& Gatignon, H. (2003). Firms and the Creation of the New Markets. Insead Working Paper.

Arundel, A., \& Rose, A. (1999). The diffusion of environmental biotechnology in Canada: adoption strategies and cost offsets. Technovation, 19(9), 551-560. http://dx.doi.org/10.1016/S0166-4972(99)00058-9

Becker, F., \& Englmann, F. (2005). Public policy, voluntary initiatives and water benign process innovations: empirical evidence from the West German chemical industry during the Mid-1990s. Weber, M., \& Hemmelskamp, J. (Eds.).

Berkhout, F., Iizuka, M., Nightingale, P., \& Voss, G. (2003). Innovation in the chemicals sector and the new European Chemicals Regulation. SPRU, University of Sussex (report for WWFUK).

Bernauer, T., Engels, S., Kammerer, D., \& Seijas, J. (2006). Explaining Green Innovation Ten Years after Porter's Win-Win Proposition: How to Study the Effects of Regulation on Corporate Environmental Innovation? Center for Comparative and International Studies, $\mathrm{N}^{\circ} 17,2006$.

Cleff, T., \& Rennings, K. (1999). Determinants of Environmental Product and Process Innovation - Evidence from the Mannheim Innovation Panel and a Follow-Up Telephone Survey. European Environment, 9(5), 191-201.

Del Río, G. P. (2005). Analysing the Factors Influencing Clean Technology Adoption: A Study of the Spanish Pulp and Paper Industry. Business Strategy and the Environment, 14(1), 20-37. http://dx.doi.org/10.1002/bse.426

Del Río, G. P. (2009). The empirical analysis of the determinants for environmental technological change: A research agenda. Ecological Economics, 68(3), 861-878. http://dx.doi.org/10.1016/j.ecolecon.2008.07.004

Frondel, M., Horbach, J., \& Rennings, K. (2005). What triggers environmental management and innovation? Empirical evidence from Germany. European Congress of Environmentale and Ressouce Economics. Bremen.

Frondel, M., Horbach, J., \& Rennings, K. (2007). End-of-Pipe or Cleaner Production? An Empirical Comparison of Environmental Innovation Decisions Across OECD Countries. ZEW Discussion Paper. Retrieved from ftp://ftp.zew.de/pub/zew-docs/dp/dp0482.pdf.

Hemmelskamp, J. (1996). Environmental Policy Instruments and their Effects on Innovation. European Planning Studies, 5(2), 177-194. http://dx.doi.org/10.1080/09654319708720392 
Heraud, B. (2008, January 10). Produits d'entretien verts: les Français en quête de clarté. Marketing Magazine, 125.

http://www.e-marketing.fr/Marketing-Magazine/Article/Produits-d-entretien-verts-les-Fran-ais-en-quete-declarte-27095-1.htm.

Horbach, J. (2008). Determinant of Environmental Innovation-New Evidence from German Panel Data sources. Research Policy, 37(1), 163-173. http://dx.doi.org/10.1016/j.respol.2007.08.006

Horbach, J., \& Rennings, K. (2007). Panel Survey Analysis of Eco-Innovation: Possibilities and Propositions. ZEW Discussion Paper.

Iraldo, F., Testa, F., Melis, M., \& Frey, M. (2011). A Literature Review on the Links between Environmental Regulation and Competitiveness. Environmental Policy and Governance, 21(3), 210-222. http://dx.doi.org/10.1002/eet.568

ISO. (2012). ISO 14001. International Organisation for Standardization. Retrieved from http://www.iso14001.fr/.

Jaffe, A., Newell, R., \& Stavins, R. (2002). Environmental Policy and Technological Change. Environmental and Resource Economics, 22, 41-69. http://dx.doi.org/10.1023/A:1015519401088

Johnstone, N., Hascic, I., \& Ostertag, K. (2007). Environmental Policy, Technological Innovation and Patent Activity. ENV/EPOC/WPNEP(2007)5/FINAL.

Kammer, D. (2009). The effects of customer benefit and regulation on environmental product innovation. Empirical evidence from appliance manufactures in Germany. Ecological Economics, 68(8-9), 2285-2295.

Kemp, R., \& Pontoglio, S. (2008). The innovation effects of environmental policy instruements- a typical case of the blid men and the elephant. Paper for DIME WP 2.5 Workshop on Empirical Analyses of Environmental Innovations, Fraunhofer Institute for Systems and Innovation Research (ISI), Karlsruhe, January, 17th-1 $8^{\text {th }}$.

Kivimaa, P. (2007). The Determinants of Environmental Innovation: the Impacts of Environmental Policies on the Nordic Pulp, Paper and Packaging Industries. European Environment, 17(2), 92-105. http://dx.doi.org/10.1002/eet.442

Klemmer, P. (1999). Innovation Effects of Environmental Policy Instruments. Analytica, Berlin.

Kosaric, N. (1992). Biosurfactants in industry. Pure \& Appl. Chem., 64(11), 1731-1737. http://dx.doi.org/10.1351/pac199264111731

La Fleur. (2009). Nouvelles du label écologique européen. ํ⒉ Commission européenne.

Lanoie, P., Johnstone, N., Lucchetti, J., \& Ambec, S. (2007). Environmental policy, innovation and performance: new insights on the Porter hypothesis. Working Paper GAEL, 7, 36.

Mazzanti, M., \& Zoboli, R. (2006). Examining the factors influencing environmental innovation. FEEM, Nota di lavoro 20 .

Meylheuc, T., Herry, J. M., \& Bellon-Fontaine, M. N. (2001). Les biosurfactants, des biomolécules à forte potentialité d'application. Sciences des aliments, 21(6), 591-649. http://dx.doi.org/10.3166/sda.21.591-649

Mickwitz, M., Hyvättinen, H., \& Kivimaa, P. (2008). The role of policy instruments in the innovation and diffusion of environmentally friendlier technologies: popular claims versus case study experiences. Journal of Cleaner Production, 16(S1), S162-S170. http://dx.doi.org/10.1016/j.jclepro.2007.10.012

Montalvo, C. (2008). General wisdom concerning the factors affecting the adoption of cleaner technologies: a survey 1990-2007. Journal of Cleaner Production, 16(S1), S7-S13. http://dx.doi.org/10.1016/j.jclepro.2007.10.002

Mowery, D. C., \& Rosenberg, N. (1979). The Influence of Market Demand Upon Innovation - A Critical Review of Some Empirical Studies. Research Policy, 8(2), 102-153. http://dx.doi.org/10.1016/0048-7333(79)90019-2

Nadai, A. (1998). Concurrence dans la qualification environnementale des produits. Revue d'économie industrielle, 83, 197-212.

Nameroff, T. J., Garant, R. J., \& Albert, M. B. (2004). Adoption of green chemistry: an analysis based on US patents. Research Policy, 33(6-7), 959-974.

Nemet, G. F. (2009). Demand-pull, technology-push, and government-led incentives for non-incremental technical change. Research Policy, 38(5), 700-709. http://dx.doi.org/10.1016/j.respol.2009.01.004 
Nordbeck, R., \& Faust, M. (2003). European Chemicals regulation and its effect on innovation: an assessment of EU's withe paper on the strategy for future chemicals policy. European Environment, 13(2), 79-99. http://dx.doi.org/10.1002/eet.313

OCDE. (1998). La biotechnologie au service de produits et de procédés industriels propres.

OCDE. (2010). La fiscalité, l'innovation et l'environnement. Edition, OCDE.

Oosterhuis, F. (2006). Substitution of hazardous chemicals: a case study in the framework of the project, assessing innovation dynamics induced by environment policy. E-07/03.

Pavitt, K. (1984). Sectoral Patterns of Technical Change: Towards a Taxonomy and a Theory. Research Policy, 13(6), 343-373. http://dx.doi.org/10.1016/0048-7333(84)90018-0

Popp, D., Hafner, T., \& Johnstone, N. (2007). Policy vs. Consumer Pressure: Innovation and Diffusion of Alternative Bleanching Technologies in the Pulp Industry. NBER Working Paper, $\mathrm{N}^{\circ} 13439$. Sept.

Porter, M. E., \& Van Der Linde, C. (1995). Towards a New Conceptualization of the Environment-Competitiveness Relationship. Journal of Economic Perspectives, 9(4), 97-118. http://dx.doi.org/10.1257/jep.9.4.97

Radonji, G., \& Tomin, P. (2000). The role of management system on introduction of new technologies in the metal and chemical. Paper: plastics industries.

Rehfeld, K., Rennings, K., \& Ziegler, A. (2007). Integrated Product Policy and Environmental Product Innovations: an empirical analysis. Ecological Economics, 61(1), 91-100. http://dx.doi.org/10.1016/j.ecolecon.2006.02.003

Rennings, K. (2000). Redefining Innovation-Eco-innovation Research and the Contribution from Ecological Economics. Ecological Economics, 32(2), 319-322. http://dx.doi.org/10.1016/S0921-8009(99)00112-3

Rennings, K., Ziegler, A., Ankele, K., \& Hoffmann, E. (2006). The influence of different characteristics of the EU Environmental Management and Auditing Scheme on technical environmental innovations and

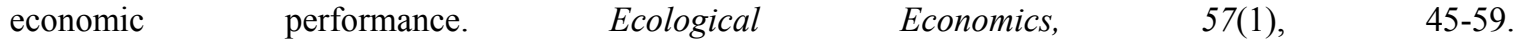
http://dx.doi.org/10.1016/j.ecolecon.2005.03.013

Rex, R., \& Baumann, H. (2007). Beyond ecolabels: what green marketing can learn from conventional marketing. Journal of Cleaner Production, 15(6), 567-576. http://dx.doi.org/10.1016/j.jclepro.2006.05.013

Rogers, E. M. (1995). Diffusion of Innovations (4th ed.). New York, Free Press.

Seijas-Nogareda, J. (2007). Determinants of Environmental Innovation in the German and Swiss Chemical Industry - With Special Consideration of Environmental Regulation. ETH Zurich, Zurich, Switzerland.

Traore, N., \& Rose, A. (2003). Determinants of biotechnology utilization by the Canadian industry. Research Policy, 32(10), 1719-1735. http://dx.doi.org/10.1016/S0048-7333(03)00081-7

Triebswetter, U., \& Wackerbauer, J. (2008). Integrated environmental product innovation in the region of Munich and its impact on company competitiveness. Journal of Cleaner Production, 16(14), 1484-1493. http://dx.doi.org/10.1016/j.jclepro.2007.09.003

Türpitz, K. (2004). The determinants and effects of environmental Product innovations - An Analysis on the base of case studies. Zew Discussion Paper, 04-02.

Verma, V. K., Bram, S., \& Ruyck, J. D. (2009). Small scale biomass heating systems: Standards, quality labeling, and market driving factors-An EU outlook. Biomass and bioenergy, 33, 1393-1402. http://dx.doi.org/10.1016/j.biombioe.2009.06.002

Visser, R., Jongen, M., \& Zwetsloot, G. (2008). Business-driven innovations towards more sustainable chemical products. Journal of Cleaner Production, 16(S1), S85-S94. http://dx.doi.org/10.1016/j.jclepro.2007.10.007

Vollebergh, H. (2007). Impacts of environmental policy instruments on technological change. OECD Report. $07-\mathrm{Feb}$.

Wagner, M. (2008). Empirical influence of environmental management on innovation: evidence from Europe. Ecological Economics, 66(2-3), 392-402. http://dx.doi.org/10.1016/j.ecolecon.2007.10.001

Ziegler, A. (2005). The determiants of Environmental Innovations: A comparison between Multinomial logit and Probit Models. ZEW. 


\section{Notes}

Note 1. In this study, we mean under the name "biomoleculars" all new natural and renewable raw materials (of plants, organic or other origin) that can be used in the formulation of new products. See for exemple Kosaric (1992); OCDE (1998); Meylheuc et al. (2001); ADEME (2007).

Note 2. Actu-Environnement.com (2011). The sub-sector of soap, fragrances and maintenance product.

Note 3. Heraud, B. (2008).

Note 4. Between 2005 and 2010, only 40 companies have adopted European Ecolabel.

Note 5. See Reheld et al. (2007); Horbach (2008); Kivima (2007); Frondel et al.(2005); Rennings et al.(2006); Frondel et al. (2007); Bernauer et al. (2006); Mazzanti and Zoboli (2006); Kemp and Pontoglio (2008); Del Río (2009); Del Río (2005); Popp et al. (2007); Johnstone et al. (2007); Triebswetter and Wackerbauer (2008); Kammerer (2009); Montalvo, (2008); Mickwitz et al. (2008); Hemmelskamp (1996).

Note 6. For a detailed review see Jaffe et al. (2002); Vollebergh (2007); Iraldo et al. (2011); Del Río (2009); Kemp and Pontoglio (2008); OECD (2010); Mickwitz et al. (2008); Ambec and Lanoie (2008).

Note 7. See Kammerer (2009); Del Río (2005).

Note 8. Integrated Pollution Prevention and Control.

Note 9. Environmental certification may also be another determinant factor of innovation (Frondel et al., 2007; Rehfeld et al., 2007; Verma et al., 2009; Cleff and Rennings, 1999; Rennings et al., 2006; Wagner, 2008). Moreover, in our case, we test ISO 9001 variable only. The European Ecolabel specification is more emphasis on quality process control and taking into account the environmental impact on the lifecycle product, but without impose the use of LCA (Life Cycle Analysis). In addition, it is in this case (our study) a certification product and this is what makes the other variables, for us, less critical, such as LCA and other certifications ISO 14001or EMAS. These, as our model assumed above, can be at the same time in competition with the European Ecolabel certification. Finally, our sample size, as we will see, does not enable us to test a larger number of variables.

Note 10. We introduced the terms "knowledge" and "competition". The first to specify in the model that there is also a transfer of knowledge, not only information. The second also shows that the process is at the same time a process of competition, cooperation, collaboration and construction of different networks.

Note 11. Big (more than 500 employees), medium (between 51 and 500 employees) and small (less equal or less than 50 employees).

Note 12. Old (more than 20 years), medium (between 10 and 20 employees) and young (less than 10 years).

Note 13. Ecocert (French private Ecolabel certification); EU Eco-Management and Audit Scheme (EMAS); Life Cycle Analysis (LCA). The choice of this certifications categories is particularly motivated by the dominant environment in the professional French market.

Note 14. National Institute of Statistics and Economics Studies.

Note 15. Type 1: voluntary, multiple-criteria-based, third-party program that awards a license that authorizes the use of environmental labels on products indicating overall environmental preference of a product within a particular product category based on life cycle; type II: informative environmental self-declaration claims; type III: voluntary programs that provide quantified environmental data of a product, under pre-set categories of parameters set by a qualified third party and based on lifecycle assessment, and verified by that or another qualified third party (ISO-defined voluntary label schemes). $88 \%$ of firms surveyed claim having developed green product and $40 \%$ Ecocert certified products.

Note 16. All studies are not specified to voluntary policies. 